Richard M. Smiley MD PhD, Eugene Ornstein MD PhD, Eugene J. Pantuck MD, Carol B. Pantuck BA, Richard S. Matteo MD

\title{
Metabolism of des- flurane and isoflurane to fluoride ion in surgical patients
}

\begin{abstract}
The metabolism of isoflurane and the investigational volatile anaesthetic desflurane to fluoride ion was examined in 25 surgical patients. The patients were randomly assigned to four groups, to receive isoflurane or desflurane at either $0.65 \mathrm{MAC}$ or 1.25 MAC. Anaesthesia was induced in all patients with thiopentone and midazolam and included nitrous oxide $60 \%$ in addition to the volatile agent. Blood was drawn before induction and at the end of the operation for determination of serum fluoride ion concentration. Plasma fluoride ion concentrations increased $(+1.36 \pm 0.93 \mu M, P<0.01)$ in patients receiving isoflurane but were unchanged $(-0.13 \pm 0.50 \mu M)$ in patients receiving desflurane. Metabolic release of fluoride ion is less with desflurane than with isoflurane during administration of the anaesthetics to surgical patients, and is unlikely to be of clinical significance.
\end{abstract}

Le mérabolisme de l' isoflurane et de l'anesthésique volatil sous investigation le desflurane en ion fluorure fut examiné chez 25 patients chirurgicaux. Les patients furent randomisés et divisés en quatre groupes afin de recevoir l' isoflurane ou le desflurane d soit 0,65 MAC ou 1,25 MAC. L'anesthésie fut induite chez tous les patients avec du thiopentone et du midazolam incluant du protoxyde d'azote $60 \%$ avec l'agent volatil. Du sang fut prélevé avant l'induction et à la fin de l'opération afin de déterminer la concentration d' ion fluorure sérique. Des concentrations des ions fluorure plasmatique augmentèrent $1+1,36 \pm$ $0,93 \mu \mathrm{M}, P<0,01)$ chez les patients recevant l'isoflurane mais furent inchangées $(-0,13 \pm 0,50 \mu M)$ chez les patients

\section{Key words}

ANAESTHETICS, VOLATILE: desflurane, isoflurane, metabolism;

IONS: fluoride.

From the Department of Anesthesiology, Columbia University College of Physicians and Surgeons, 630 West 168th Street,

Milstein Hospital Building 4-446, New York, NY 10032.

This work was supported in part by funding from Anaquest Corp., Division of BOC Inc.

Address correspondence to: Dr. R.M. Smiley.

Accepted for publication 28th May, 1991. recevant la desflurane. La libération mérabolique de l'ion fluorure est moindre avec la desflurane que l' isoflurane durant l'administration de l'anesthésie chez les patients chirurgicaux et n'aura probablement pas de signification clinique.

Desflurane (difluoromethyl 1-fluoro 2,2,2-trifluoroethyl ether) is a new volatile anaesthetic currently undergoing clinical investigation. It has several physicochemical properties which may contribute to its clinical utility. The blood/gas partition coefficient of desflurane is 0.42 which is significantly lower than all clinically used halogenated agents, and slightly less than that of nitrous oxide $(0.46){ }^{1,2}$ This property predicts more rapid induction of and emergence from anaesthesia with desflurane than of other potent volatile agents; this has been confirmed in animal experiments and human studies. ${ }^{3-6}$ As is the case with methoxyflurane, enflurane, and isoflurane, inorganic fluoride is a product of desflurane metabolism. Lack of a chlorine atom in the desflurane molecule should render it resistant to metabolic breakdown, and studies in animals and volunteers have demonstrated little metabolism. ${ }^{7-10}$ Renal toxicity from inorganic fluoride can occur following anaesthesia with methoxyflurane or enflurane, but this has never been observed following anaesthesia with the much less metabolized isoflurane. ${ }^{11-13}$ We have examined the metabolism of desflurane to fluoride and compared it with the metabolism of isoflurane in patients randomly assigned to receive one or the other agent for surgical anaesthesia.

\section{Methods}

\section{Subjects}

The study had the approval of the Institutional Review Board of the Columbia-Presbyterian Medical Center, and written informed consent was obtained from all subjects. Twenty-eight patients, aged 18-64 yr, weight 50-100 $\mathrm{kg}$, were studied during elective surgery. Due to problems in sample handling, both preoperative and postoperative plasma samples were obtained from 25 of the 28 patients ( 7 women, $18 \mathrm{men}$ ). None of the operations was intra- 
TABLE I Patient data

\begin{tabular}{lllllll}
\hline Group & Anaesthetic dose & $M$ & $F$ & Age $(y r)$ & $\begin{array}{l}\text { Weight } \\
(\mathrm{kg})\end{array}$ & $\begin{array}{l}\text { Exposure } \\
\text { time (min) }\end{array}$ \\
\hline 1 & Desflurane 0.65 & 5 & 2 & $43 \pm 16$ & $72.9 \pm 11.0$ & $132 \pm 46$ \\
2 & Isoflurane 0.65 & 4 & 3 & $45 \pm 16$ & $76.2 \pm 8.9$ & $108 \pm 49$ \\
3 & Desflurane 1.25 & 4 & 1 & $52 \pm 14$ & $79.5 \pm 12.8$ & $165 \pm 86$ \\
4 & lsoflurane 1.25 & 5 & 1 & $44 \pm 15$ & $70.1 \pm 13.1$ & $129 \pm 66$ \\
\hline
\end{tabular}

Values are mean \pm SD.

No significanit differences among groups.

abdominal, intrathoracic, or intracranial, and all were expected to last at least $60 \mathrm{~min}$. The patients were all ASA physical status 1 or 2 , and had not taken medications known to affect anaesthetic depth or induce hepatic enzyme activity, nor ingested significant amounts of ethanol for at least seven days before surgery. No women of childbearing potential were studied, and none of the females was taking any oestrogen-containing drugs. Baseline laboratory values including serum electrolytes, BUN, creatinine, complete blood count, liver function tests and ECG were all within normal limits.

\section{Conduct of ancesthesia}

Patients were randomly assigned to one of four groups, each to receive a specific concentration (0.65 MAC or 1.25 MAC) of isoflurane or desflurane along with $60 \%$ nitrous oxide in oxygen for maintenance of anaesthesia. Patients in Group 1 received isoflurane $0.65 \mathrm{MAC}$, those in Group 2 received desflurane 0.65 MAC. Patients in Group 3 received isoflurane 1.25 MAC, while those in Group 4 received desflurane 1.25 MAC. The values for MAC used were $1.28 \%$ for isoflurane and $7.25 \%$ for desflurane. ${ }^{6}$ For desflurane, this resulted in end-tidal concentrations of $4.7 \%(0.65 \mathrm{MAC})$ and $9.1 \%$ (1.25 MAC); for isoflurane the concentrations were $0.8 \%$ and $1.6 \%$.

The subjects did not receive premedication. During placement of the intravenous catheter in the operating suite, a blood sample was drawn for determination of plasma fluoride concentration. Midazolam $0.03 \mathrm{mg} \cdot \mathrm{kg}^{-1}$ was administered iv 5-15 min before anaesthetic induction. End-tidal concentrations of carbon dioxide, nitrous oxide, oxygen, and isoflurane or desflurane were determined with a modified Datex 254 Airway Gas Analyzer (Puritan Bennett Corp.). Patients receiving isoflurane were anaesthetized using the standard anaesthesia machine in the particular operating room. Desflurane was administered via a modified Ohmeda DM5000 machine equipped with a temperature-controlled vaporizer and pressurized to approximately two atmospheres to allow controlled delivery of desflurane, a compound with a boiling point of $23.5^{\circ} \mathrm{C}$ at atmospheric pressure. Anaesthesia was induced with thiopentone. Mask ventilation was instituted with slowly increasing concentrations of isoflurane or desflurane in $60 \% \mathrm{~N}_{2} \mathrm{O} / 40 \%$ oxygen. Tracheas were intubated after satisfactory anaesthetic depth was achieved, and the anaesthetic concentration was adjusted to the appropriate end-tidal concentration and maintained constant until near the end of surgery. None of the operations involved major blood loss, and intravenous fluids were administered as needed in the form of lactated Ringer's solution. A venous blood sample was obtained at the end of the surgical procedure for determination of the postoperative plasma fluoride concentration.

\section{Plasma fluoride determination}

Plasma was isolated from the blood samples by centrifugation at $1500 \times \mathrm{g}$ for ten minutes and stored at $-25^{\circ} \mathrm{C}$ until analysis. Fluoride concentrations in plasma were determined using an ion specific electrode (Orion Research, Boston, MA, Model 96-09 with pH meter Model EA 940) as described by Fry and Taves. ${ }^{14}$ The concentration of fluoride in the pre-induction sample was subtracted from the concentration in the postoperative sample and the difference reported as $\Delta \mathrm{F}$. The limit of detection for the assay is $0.5 \mu \mathrm{M}$. Reproducibility of electrode measurements is $\pm 2 \%$ (Orion Corporation). The coefficient of variation of the assay at the fluoride concentrations measured during this study is approximately $7 \%$.

\section{Data analysis}

Preoperative and postoperative fluoride ion concentrations within each group were compared with a paired t test. Comparisons among groups were made by analysis of variance, and statistical significance confirmed by Scheffe F test, with correction for multiple comparisons. $P$ values of $<0.05$ were considered statistically significant. Correlation of changes in fluoride concentration with anaesthetic exposure was performed by linear regression. Values are expressed as mean \pm standard deviation.

\section{Results}

There were no significant differences among the groups with regard to age, weight, or average anaesthetic exposure times, although desflurane exposures tended to be slightly longer (Table I). 


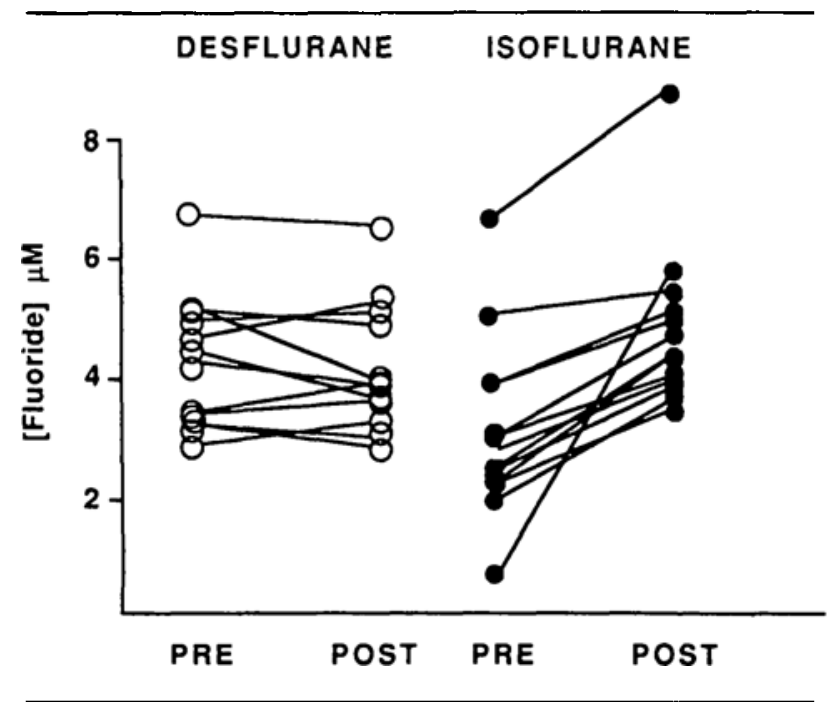

FIGURE 1 Pre-induction and immediate postoperative plasma fluoride concentrations in individual surgical patients receiving either isoflurane (closed circles, $n=13$ ) or desflurane (open circles, $n=12$ ).

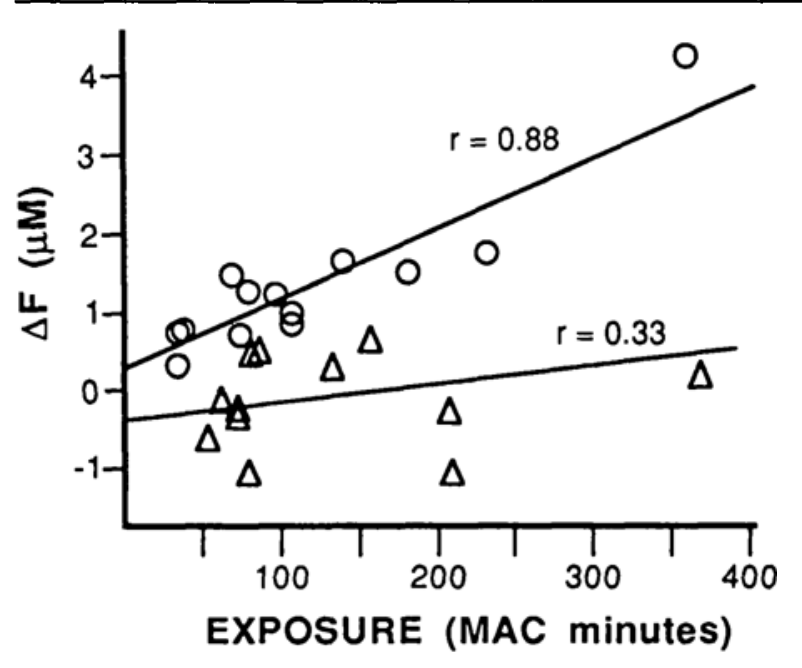

FIGURE 2 Perioperative change in plasma fluoride ion concentration $(\triangle F)$ versus total anaesthetic exposure (MAC minutes) in paticnts anaesthetized with isofluranc (circles) or desflurane (triangles).

TABLE II Perioperative changes in plasma fluoride concentrations

\begin{tabular}{llllll}
\hline Anaesthetic & $n$ & $\begin{array}{l}\text { Exposure } \\
(\text { MAC minutes })\end{array}$ & $\begin{array}{l}{\left[F^{-}\right] \text {preop }} \\
(\mu M)\end{array}$ & $\begin{array}{l}\left(F^{-}\right] \text {posiop } \\
(\mu M)\end{array}$ & $\begin{array}{l}\Delta F \\
(\mu M)\end{array}$ \\
\hline Desfluranc & 12 & $135 \pm 92$ & $4.30 \pm 1.13$ & $4.17 \pm 1.09$ & $-0.13 \pm 0.50^{*}$ \\
Isoflurane & 13 & $126 \pm 92$ & $3.76 \pm 1.27$ & $5.12 \pm 1.18$ & $1.36 \pm 0.93$ \\
\hline
\end{tabular}

Values are mean \pm SD.

$* P<0.01$ versus isoflurane.

\section{Plasma fluoride}

Plasma fluoride did not change over the course of anaesthesia in either desflurane group. In Group $2(0.65$ MAC desflurane), preoperative mean $\left[\mathrm{F}^{-}\right]$was $4.1 \pm 0.9$ $\mu \mathrm{M}$, while postoperative $\left[\mathrm{F}^{-}\right]$was $3.9 \pm 0.5 \mu \mathrm{M}(\Delta \mathrm{F}=$ $-0.2 \pm 0.6 \mu \mathrm{M})$. In Group 4 , preoperative $\left[\mathrm{F}^{-}\right]$was 4.6 $\pm 1.5 \mu \mathrm{M}$, with a postoperative concentration of $4.6 \pm$ $1.6(\Delta \mathrm{F}=0 \pm 0.4 \mu \mathrm{M})$. The largest increase in the desflurane groups was $0.58 \mu \mathrm{M}$, in a patient with an exposure of 167.5 MAC-minutes (1.25 MAC for 134 $\mathrm{min}$ ). Serum fluoride levels increased in both isoflurane groups; in Group 1 (0.65 MAC) mean [ $\mathrm{F}^{-}$] increased from $3.8 \pm 0.8 \mu \mathrm{M}$ to $4.8 \pm 0.6 \mu \mathrm{M}(\Delta \mathrm{F}=1.00 \pm 0.38 \mu \mathrm{M}$, $P=0.0004)$, and in Group 3 mean $\left[\mathrm{F}^{-}\right]$increased from $3.7 \pm 1.7 \mu \mathrm{M}$ to $5.5 \pm 1.6 \mu \mathrm{M}(\Delta \mathrm{F}=1.8 \pm 1.2 \mu \mathrm{M}, P$ $=0.016$ ). One patient had an increase of $4.15 \mu \mathrm{M}$ (exposure 360 MAC minutes). All 13 isoflurane patients had increases in serum fluoride, while only five of the 12 desflurane patients had increases (Figure 1). There was no difference in serum fluoride changes between the two isoflurane groups or between the two desflurane groups, but both desflurane groups had a smaller change in serum fluoride than either group receiving isoflurane. Since increases in serum fluoride (with isoflurane) correlated with total exposure (MAC minutes) rather than with the particular concentration administered (Figure 2), the two groups receiving each anaesthetic were combined for analysis in Table II.

\section{Discussion}

Before anaesthesia, all patients had measurable concentrations of inorganic fluoride in plasma. These levels are slightly higher than in some other published reports, ${ }^{10,15,17,18}$ and are probably due to fluoridation of most water supplies in the New York area. At the termination of anaesthesia, the concentration of inorganic fluoride in plasma was increased in the patients who had received isoflurane but was unchanged in the patients who had received desflurane. These results indicate that during anaesthesia desflurane was metabolized less than isoflurane. We did not measure plasma fluoride at any later time after surgery, although inorganic fluoride can continue to be produced following termination of anaesthetic administration as a result of metabolism of drug released from tissue stores, primarily adipose tissue. This occurs to only a small extent with isoflurane, ${ }^{15}$ and in view of its low 
level of metabolism, lower fat solubility, and rapid elimination, would be expected to be even less important with desflurane. It has been reported that following enflurane administration, the serum fluoride concentration measured a few hours postoperatively had increased about $25 \%$ from that measured at the end of surgery. ${ }^{15,16}$ Isoflurane is eliminated from the body more rapidly after discontinuation of the anaesthetic, presumably due to lower blood and tissue solubility, resulting in no significant post-anaesthetic increase in plasma fluoride. ${ }^{18}$ Desflurane would be expected to be even more rapidly eliminated than isoflurane; thus it is extremely unlikely that plasma fluoride levels would rise after surgery due to anaesthetic metabolism. ${ }^{7}$

We did not measure intra- and post-anaesthetic urinary excretion of inorganic or organic fluoride by our subjects and therefore cannot make a quantitative estimate of the difference in the extent of metabolism between isoflurane and desflurane.

Serum inorganic fluoride levels of $40-50 \mu \mathrm{M}$ have been reported to result in mild defects in urine concentrating ability with more severe changes in urine concentrating ability and renal damage occurring when $\left[\mathrm{F}^{-}\right]$is in the range of $100 \mu \mathrm{M}$ or greater. ${ }^{18}$ Moderately prolonged exposure to methoxyflurane can result in serum fluoride levels of a magnitude sufficient to produce significant postoperative renal impairment. " Fluoride levels greater than $40 \mu \mathrm{M}$ have occasionally been associated with enflurane administration, especially in the presence of drug-induced liver enzyme induction. ${ }^{15,17}$ Case reports of postoperative renal dysfunction related to enflurane have been published, but this appears to be a rare event, because plasma levels of fluoride decrease more rapidly after enflurane than after methoxyflurane administration. ${ }^{12.13}$ Nephrotoxic concentrations of fluoride have not been observed following isoflurane anaesthesia. Metabolism of desflurane has been found to increase in rats pretreated with ethanol or phenobarbitone but to a much lower level than the small increase seen with isoflurane. ${ }^{8}$ The possibility of enzyme induction or other intervention producing an increase in desflurane metabolism of a magnitude sufficient to result in nephrotoxic levels of inorganic fluoride is very remote. Desflurane appears to be a safe anaesthetic with respect to the potential for fluoride-induced nephrotoxicity.

\section{References}

1 Eger EI II. Partition coefficients of I-653 in human blood, saline, and olive oil. Anesth Analg 1987; 66: 971-3.

2 Eger EI II. Anesthetic Uptake and Action. Baltimore/ London: Williams and Wilkins, 1974: 77-96.

3 Eger EI II, Johnson BH. Rates of awakening from anes- thesia with I-653, halothane, isoflurane, and scvoflurane: a test of the effect of anesthetic concentration and duration in rats. Ancsth Analg 1987; 66: 977-82.

4 Yasuda N, Lockart SH, Eger EI II, Weiskopf RB, Johnson $B H$, Faussolaki $A$. Desflurane, isoflurane, and halothane pharmacokinetics in humans. Anesth Analg 1990; 70: S444.

5 Jones RM, Cashman JN, Mant TGK. Clinical impressions and cardiorespiratory effects of a new fluorinated inhalation anaesthetic, desflurane (I-653), in volunteers. $\mathrm{Br}$ J Anaesth 1990; 64: 11-5.

6 Smiley RM, Ornstein E, Matteo RS, Pantuck EJ, Pantuck $C B$. Desflurane versus isoflurane in surgical patients comparison of cmergence time. Anesthesiology 1991; 74: 425-8.

7 Sutton TS, Koblin DD, Weiskopf RB, Gruenke LD, Waskell $L$, Eger EI II. Fluoride metabolites following prolonged exposure of volunteers to desflurane. Anesth Analg 1990; 70: S398.

8 Koblin DD, Eger EI II, Johnson BH, Konopka K, Waskell L. I-653 resists degradation in rats. Anesth Analg 1988; 67: 534-8.

9 Koblin DD, Weiskopf RB, Holmes MA et al. Metabolism of I-653 and isoflurane in swine. Anesth Analg 1989; 68: 147-9.

10 Jones RM, Koblin DD, Cashman JN, Eger EI II, Johnson $B H$, Damask $M C$. Biotransformation and hepato-renal function in volunteers after exposure to desflurane (I-653). Br J Anaesth 1990; 64: 482-7.

11 Cousins MJ, Mazze RI. Methoxyflurane nephrotoxicity. A study of the dose-response in man. J Am Med Soc 1973; 225: 1611-6.

12 Eichhorn JH, Hedley-Whyte J, Steinman $T l$ et al. Renal failure following enflurane anesthesia. Anesthesiology 1976; 45: 557-60.

13 Loehning RW, Mazze RI. Possible nephrotoxicity from enflurane in a patient with severe renal disease. Anesthesiology 1974; 40: 203-5.

14 Fry $B W$, Taves DR. Serum fluoride analysis with the fluoride electrode. J Lab Clin Med 1970; 75: 1020-5.

15 Cousins MJ, Greenstein LR, Hitt BA, Mazze RI. Metabolism and renal effects of enflurane in man. Anesthesiology 1976; 44: 44-53.

16 Dooley JR, Mazze RI, Rice SA, Borel JD. Is enflurane defluorination inducible in man? Anesthesiology 1979; 50: 213-7.

17 Dobkin AB, Kim D, Choi JK, Levy AA. Blood serum fluoride leveis with enflurane (Ethrane) and isoflurane (Forane) anaesthesia during and following major abdominal surgery. Can Anaesth Soc J 1973; 20: 494-8.

18 Mazze RI, Cousins MJ, Barr GA. Renal effects and metabolism of isoflurane in man. Anesthesiology 1974; 40: 536-42. 